\title{
Temporal variations of zooplankton biomass in the Ligurian Sea inferred from long time series of ADCP data
}

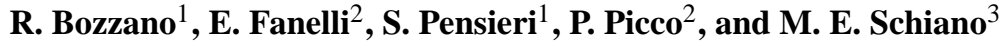 \\ ${ }^{1}$ National Research Council of Italy (CNR-ISSIA) - Via de Marini 6, 16149, Genova, Italy \\ ${ }^{2}$ Marine Environment Research Centre (ENEA) - Santa Teresa, Pozzuolo di Lerici 19032, Italy \\ ${ }^{3}$ National Research Council of Italy (CNR-ISMAR) - Via de Marini 6, 16149, Genova, Italy \\ Correspondence to: R. Bozzano (roberto.bozzano@cnr.it)
}

Received: 8 July 2013 - Published in Ocean Sci. Discuss.: 16 August 2013

Revised: 8 January 2014 - Accepted: 21 January 2014 - Published: 21 February 2014

\begin{abstract}
Three years of $300 \mathrm{kHz}$ acoustic doppler current profiler data collected in the central Ligurian Sea are analysed to investigate the variability of the zooplankton biomass and the diel vertical migration in the upper thermocline. After a pre-processing phase aimed at avoiding the slant range attenuation, hourly volume backscattering strength time series are obtained. Despite the lack of concurrent net samples collection, different migration patterns are identified and their temporal variability examined by means of time-frequency analysis. The effect of changes in the environmental condition is also investigated. The highest zooplankton biomasses are observed in April-May just after the peak of surface primary production in March-April. The main migration pattern found here points to a "nocturnal" migration, with zooplankton organisms occurring deeper in the water column during the day and shallower at night. Also, twilight migration is highlighted during this study. The largest migrations are recorded in November-December, corresponding to lowest backscattering strength values and they are likely attributable to larger and more active organisms (i.e. euphausiids and mesopelagic fish). The results suggest further applications of the available historical acoustic doppler current profiler time series.
\end{abstract}

\section{Introduction}

The Acoustic Doppler Current Profiler (ADCP) is a widely used instrument to monitor the marine currents. Time series of these measurements span from a few days up to several years and are available for many coastal and open ocean sites. However, ADCP data may also be usefully employed to measure biological variables as pointed out by Flagg and Smith (1989) and Plueddemann and Pinkel (1989) at the end of the 1980s, who showed that the acoustic backscatter signal was correlated with the zooplankton biomass. Since then, several biological investigations have been carried out using ADCP observations (Rippeth and Simpson, 1998; Pinot and Jansá, 2001; Jiang et al., 2007; Ashjian et al., 2002, 1994; van Haren, 2007). Unfortunately, ADCP data are more qualitative than quantitative because the conversion from backscatter intensity to equivalent zooplankton biomass, usually obtained by direct comparison against coincident data from net samples, is somewhat problematic, and the resulting relationship provides only rough estimates (Pinot and Jansá, 2001; Ashjian et al., 2002; Fielding et al., 2004). Nevertheless, the instrument, ensuring long-term autonomous monitoring, offers the opportunity to study the zooplankton distribution and its variability on many different temporal and spatial scales. Thus, its data supply important information required in marine ecology research that cannot be satisfactorily obtained using the classical observational methodology based on discrete net sampling.

Furthermore, ADCP data may help in reconstructing the diel vertical migration (DVM) of the zooplankton which is probably the biggest animal migration, in terms of biomass, on the planet (Hays, 2003). Since zooplankton represents the trophic link between primary producers (i.e. phytoplankton in the photic zone) and the higher trophic levels up to top predators, the comprehension of their migratory patterns and biomass distribution is of crucial importance in understanding the pelagic ecosystem functioning. 
In this context, the paper analyses the echo intensity and the vertical velocity data obtained from an ADCP moored in the open Ligurian Sea from September 2003 to February 2006 in terms of variations in the zooplankton biomass and DVM. These patterns are discussed, taking into account the results achieved by several different previous studies carried out in the Ligurian Sea, one of the most dynamically active regions in the Mediterranean.

Although the experiment did not include specific biological measurements, the aim of this work is to highlight the usefulness of long-term ADCP data series to enhance current knowledge on zooplankton, especially their migratory patterns.

The paper is organized into the following parts: Sect. 2 describes the investigated area, the data and the methodologies used in the study. The analysis of the zooplankton behaviour and its variability, with particular attention to the characteristic patterns of the DVM and the influence of some environmental variables, is given in Sect. 3. The results are discussed in Sect. 4.

\section{Materials and methods}

\subsection{Main features of the investigated area}

The Ligurian Sea is a 3000 m-deep basin surrounded in the north by the Alps and limited by Corsica to the south (Fig. 1). These topographic constraints as well as the thermal contrast between land and sea give rise to specific local effects that influence the general circulation of both atmosphere and ocean, causing a strong variability in the upper ocean. The general circulation of the Ligurian Basin is characterized by a permanent basin-wide cyclonic circulation involving both the surface Modified Atlantic Water (MAW) and the lower Levantine Intermediate Water (LIW) (Crepon et al., 1982; Millot, 1999); it also shows important seasonal variability (Astraldi and Gasparini, 1992). The currents are generally weaker in the summer than during the winter and the contribution from the Tyrrhenian Sea is strongly reduced in summer. Significant inter-annual variability is observed (Vignudelli et al., 2000; Birol et al., 2010), as well as an intense mesoscale activity with marked seasonal variations (Taupier-Letage and Millot, 1986; Sammari et al., 1995).

Furthermore, due to the interplay of these particular climatic, oceanographic and physiographic factors, the area is highly productive and hosts a rich and complex ecosystem. This is also sustained by vertical mixing and coastal upwelling, generated by the prevailing northwesterly wind, which pumps deep nutrients and other organic substances contributed by rivers into the euphotic zone where they fertilize growing phytoplankton populations. Hence, the area attracts several cetacean species and is part of the "Cetacean Sanctuary" protected area, established to preserve the richness and variety of cetaceans living here with more

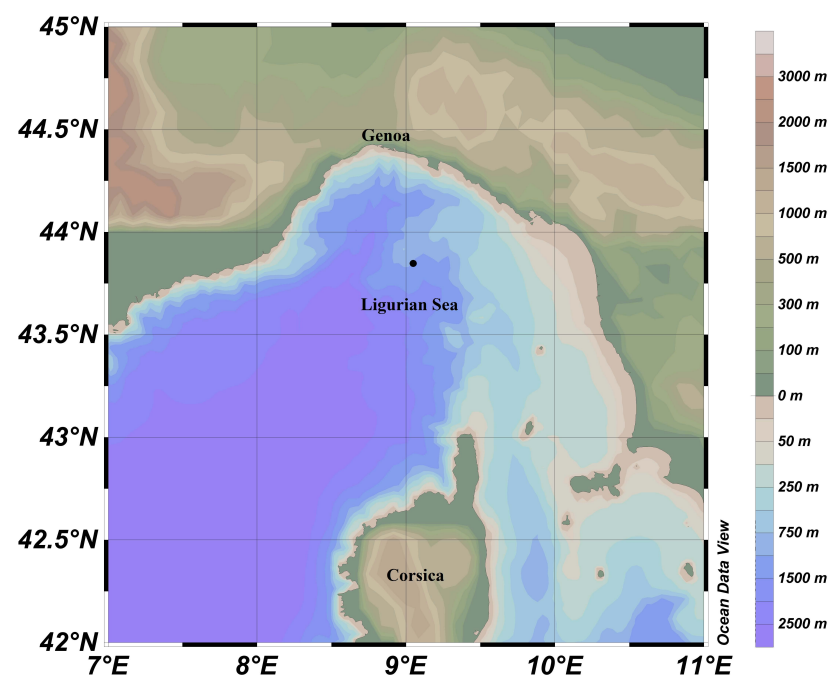

Fig. 1. Bathymetry and horography of the Ligurian region. Black dot corresponds to the mooring position.

than eight species, including the fin whale Balaenoptera physalus.

All these issues make the Ligurian Basin a meaningful research site for both physicists and biologists.

Several previous studies were conducted in the Ligurian Sea to determine the composition and biomass distribution of zooplankton communities (Licandro and Ibanez, 2000; Licandro and Icardi, 2009; Tarling et al., 2001; Andersen and Sardou, 1992; Sardou and Andersen, 1996). Although a comprehensive study which analyses the zooplankton composition at a seasonal scale in the whole Ligurian Basin is lacking, a rough reconstruction of species composition and dominance throughout the year can be done.

The mesozooplankton is mostly dominated by copepods (64\% of the total number of taxa); as a general pattern, in the entire Mediterranean Sea the bulk of the copepod population is concentrated in the epipelagic layer above $100 \mathrm{~m}$ depth with abundances decreasing sharply thereafter (Mazzocchi et al., 2007; di Carlo et al., 1984; Weikert and Trinkaus, 1990; Brugnano et al., 2011). Seasonal variations are observed in the composition of the zooplankton population with the dominance of different species throughout the year, such as Clausocalanus spp. and Fritillaria spp. in winter, and Oithona helgolandica and Temora stylifera in autumn (Licandro and Ibanez, 2000). Among the macrozooplankton/micronekton, Tarling et al. (2001) report a dominance of euphausiids (mainly Meganyctiphanes norvegica and Nematoscelis megalops) and pteropods (almost exclusively Cavolinia inflexa) in September, while mostly $\mathrm{Ne}$ matoscelis megalops is found in the Ligurian central zone in May (Andersen and Sardou, 1992). A further study by Sardou and Andersen (1996) shows that Meganyctiphanes norvegica on the coastal side of the Ligurian Front has peaks 
of abundance in February and again in August, as also confirmed by McGehee et al. (2004).

In addition, due to the particular hydrographic conditions of the area, three main assemblages may be defined: one linked to the divergence zone of the basin, one associated to the periphery of the divergence and the latter with the eastern continental shelf (Licandro and Icardi, 2009). Different mesozooplanktonic taxa describe each assemblage, being copepods of Scolecithricidae family and appendicularians of genus Fritillaria dominant in the divergence, while Clausocalanus furcatus and Paracalanus spp. mainly inhabit the eastern continental shelf. The third assemblage is mostly characterized by ostracods and the copepods Neocalanus gracilis and Clausocalanus paululus. Each assemblage is identified by different biomass values, being least in the divergence zone $\left(0.8-1.4 \mathrm{mg} \mathrm{m}^{-3}\right)$, greater at the periphery of the divergence, and at its maximum in shallower waters on the eastern continental shelf $\left(1.7-4.2 \mathrm{mg} \mathrm{m}^{-3}\right)$ close to the study area (Licandro and Icardi, 2009).

Overall, in the Mediterranean Sea, zooplankton dynamic is characterized by late winter and summer blooms which are ubiquitous in the different basins and are preceded by phytoplanktonic blooms related to environmental factors including stratification (Furnestin, 1960; Margalef, 1985). In the northwestern Mediterranean Sea the late winter zooplankton bloom is generally delayed to spring (April-May) since the peak of surface primary production is generally recorded in February-March (Andersen, 2001a; Fanelli et al., 2009).

\subsection{Environmental conditions during the period 2003-2006}

The study was carried out in three periods related to the recovery and the re-positioning at sea of the mooring (Table 1). Some unusual marine conditions occurred during each of the three periods. Particularly, the first one took place at the end of summer 2003, which was among the hottest of the last century. The anomalous warming affected the whole of Europe and, above all, the central Mediterranean and was characterized by persistent calm weather conditions from May to the end of September 2003 (Sparnocchia et al., 2006). Several mass-mortality episodes were observed along Mediterranean coasts (Garrabou et al., 2009), as the strong vertical stratification prevented vertical mixing, thus reducing the oxygen contribution from the atmosphere to the deeper layers of the ocean, and allowing intense warming of the surface waters. Only at the end of October 2003, after several strong wind events due to the passage of lows, were the upper layers completely mixed and normal conditions were again established. The second experiment was carried out during the severe winter of 2004-2005 when very intense events of deep water formation took place in the northwestern Mediterranean Sea, despite significant warming and salinification of the entire water column which occurred in this winter (Font et al., 2007). The third experiment was characterized by an anomalous long period (from April 2005 to February 2006) of very weak currents. Indeed, the recorded values did not exceed $30 \mathrm{~cm} \mathrm{~s}^{-1}$ until November when they increased during the passage of the only low system of the overall period and reached the maximum in the first days of January 2006. Moreover, winter 2005-2006 showed an abrupt change of the water mass physical characteristics (temperature and salinity) linked to deep water convection which occurred in 2006 (Smith et al., 2008). Even current direction showed a very uncommon pattern, with several episodes of eastward currents.

This significant inter-annual variability in the circulation was also evident in the horizontal currents measured by the used ADCP data (Fig. 2). Analysis for inter-annual variability was performed on the data collected from October to February since this period was available for all three deployments.

During the period 2003-2004 currents were mainly directed towards north-northwest and very few events of weak southward currents were recorded. On average, the mean hourly velocities were greater than $15 \mathrm{~cm} \mathrm{~s}^{-1}$, sometimes with peaks in the surface layers exceeding $60 \mathrm{~cm} \mathrm{~s}^{-1}$. On the contrary, during the period 2005-2006, the average velocity was less than $10 \mathrm{~cm} \mathrm{~s}^{-1}$ at all depths and the maximum values never rose above $45 \mathrm{~cm} \mathrm{~s}^{-1}$. The prevailing current was to the west and occurrences of southward currents increased.

The anomalous behaviour of the currents in the last period, both in velocity and direction, may be associated with the persistence of a high pressure system over the Ligurian Sea, inducing an extraordinary long period of calm wind condition. The anomalous conditions were also confirmed by the presence of saltier, warmer and shallower-than-normal intermediate water in the Ligurian Basin (compared with previous years) that was responsible in the first days of February 2006 for the unusual mixed layer depth of $2000 \mathrm{~m}$, in a basin where it is commonly a few hundred metres deep, and for dense water formation from February to April 2006 (Martín et al., 2010).

\subsection{Experimental setup}

An upward-looking RDI Sentinel $300 \mathrm{kHz}$ ADCP was operating in the central Ligurian Sea $\left(43^{\circ} 47.77^{\prime} \mathrm{N}, 9^{\circ} 02.85^{\prime} \mathrm{E}\right)$ from 13 September 2003 until 22 February 2006 to investigate the upper layer dynamics in the area (Picco et al., 2010).

During this period, the mooring was recovered for maintenance and redeployed twice. Each time, the water depth and hence instruments depths were inevitably slightly different, also the ADCP temporal resolution was refined for the final deployment. The whole observation period was divided into three different phases (Table 1).

The vertical displacement of the mooring was checked using pressure measurements from a CTD device installed close to the ADCP and using the distance of the ADCP to water surface computed following Visbeck and Fischer (1995). 
Table 1. Experimental configuration of the ADCP during the three deployments, from September 2003 to February 2006.

\begin{tabular}{lrrrr}
\hline Period & No. of samples & Sample frequency & Depth & Bin size \\
\hline 13 Sep 2003-24 May 2004 & 6120 & $1 \mathrm{~h}$ & $58 \mathrm{~m}$ & $8 \mathrm{~m}$ \\
23 Sep 2004-15 Apr 2005 & 4943 & $1 \mathrm{~h}$ & $100 \mathrm{~m}$ & $8 \mathrm{~m}$ \\
19 Apr 2005-22 Feb 2006 & 14934 & $30 \mathrm{~min}$ & $80 \mathrm{~m}$ & $8 \mathrm{~m}$ \\
\hline
\end{tabular}
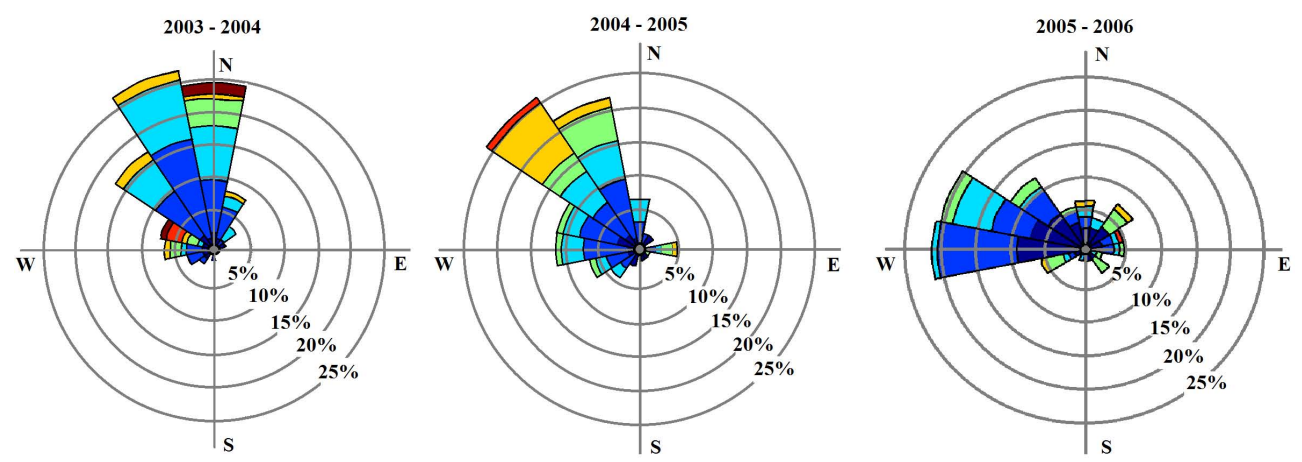

$\square 30-40 \mathrm{~cm} / \mathrm{s} \square 25-30 \mathrm{~cm} / \mathrm{s} \square 20-25 \mathrm{~cm} / \mathrm{s} \square 15-20 \mathrm{~cm} / \mathrm{s} \square 10-15 \mathrm{~cm} / \mathrm{s} \square 5-10 \mathrm{~cm} / \mathrm{s} \square 0-5 \mathrm{~cm} / \mathrm{s}$

Fig. 2. Distribution of the horizontal currents recorded at $40 \mathrm{~m}$ depth from October to February during the three deployments.

The mooring in all three periods showed good stability, indeed pitch and roll data never exceeded $2.5^{\circ}$, well below the $9^{\circ}$ limit defined by the manufacturer for tilt compensation. Pitch and roll data showed a standard deviation less than than $1^{\circ}$ for all three periods, satisfying the requirements for good velocities data (RD Instruments, 2007).

All observations were quality checked; data were considered valid only (a) if characterized by at least three beam solutions, (b) if satisfying the constraints of maximum range established by Gordon (1996) and (c) if the threshold of error velocity was not exceeded.

In all three periods the percentage of data rejected was less than $0.1 \%$. The final overall ADCP data set consists of 11063 hourly data and 14934 samples with a sampling time of $30 \mathrm{~min}$ (Table 1).

Several supplementary data were used. Particularly, the sunrise/sunset times at the mooring location were computed by using the air-sea toolbox developed at Woods Hole Science Center (http://woodshole.er.usgs.gov/ operations/sea-mat/air_sea-html/index.html), while surface wind data on the mooring site were obtained from the ERA-Interim (Dee et al., 2011) database products from the European Centre for Medium-Range Weather Forecasts (ECMWF).

In addition, values of net primary production (NPP) obtained from the vertically generalized production model based on MODIS and SeaWIFS measurements (http:// www.science.oregonstate.edu/ocean.productivity) were used as proxies of surface primary production in the area (Behrenfeld and Falkowski, 1997). Considering the normal delay of about 1 month between peaks of surface production and the increase in zooplankton biomass (Truscott and Brindley, 1994) values of NPP may help to interpret the ADCP observed profiles.

\subsection{Volume backscattering strength computation}

The measure of the echo intensity scattered by the ocean is usually given in terms of volume backscattering strength ( $\mathrm{Sv}$ hereafter) in $\mathrm{dB}$ re $(4 \pi \mathrm{m})^{-1}$. Following Deines (1999), $\mathrm{Sv}$ is computed for each depth cell along each of the four beams through Eq. (1):

$$
\begin{aligned}
\mathrm{Sv}= & C+10 \log _{10}\left(\left(T_{x}+273.16\right) R^{2}\right)-L_{\mathrm{DBM}}-P_{\mathrm{DBM}} \\
& +2 \alpha R+K_{\mathrm{c}}\left(E-E_{\mathrm{r}}\right) .
\end{aligned}
$$

$C(-143.5 \mathrm{~dB})$ is the instrumental constant of RDI profilers for Workhorse Sentinel ADCP $300 \mathrm{kHz} . T_{x}$ is the ADCP internal temperature in ${ }^{\circ} \mathrm{C}$. $R$ is the slant range defined in Eqs. (3) and (6). $L_{\mathrm{DBM}}$ is the $10 \log _{10}$ of the transmit pulse length in $\mathrm{m}$ ( $8.21 \mathrm{~m}$ for all three deployments). $P_{\mathrm{DBM}}$ is the $10 \log _{10}$ of the transmit power in Watt, defined by RDI for the ADCP model here used as $14 \mathrm{dBW}$. $E$ is the echo intensity provided by the ADCP. $E_{\mathrm{r}}$ (40 counts) is the echo reference value when there is no signal and it is specifically determined for each instrument. $K_{\mathrm{c}}$ is the factor for converting to $\mathrm{dB}$ unit the raw echo data provided by the ADCP and it is defined through Eq. (2) (RD Instruments, 2007):

$K_{\mathrm{c}}=\frac{127.3}{T_{x}+273}$.

$\alpha$ is the sound absorption coefficient for the seawater that is variable with depth, computed according to the Ainslie 
(Ainslie, 1998) formula, a simple expression which takes into account the contribution of boric acid, magnesium sulfate and pure water, and depends on temperature and salinity. These last two parameters are obtained from the climatological MED6 database, a gridded monthly mean of in situ measurements of temperature and salinity for the entire Mediterranean and the near-North Atlantic area at $0.25^{\circ}$ resolution (Brankart and Pinardi, 2001). Data from the MED6 database are selected in a $0.25^{\circ}$, square centred on $9.375^{\circ} \mathrm{E}, 43.75^{\circ} \mathrm{N}$, the grid point closest to the mooring.

$R$ is the slant range to the scattering layers being measured along the beam in metres expressed by Eq. (3):

$$
R=\frac{B+\left(\frac{L+D}{2}\right)+[(n-1) D]+\frac{D}{4}}{\cos \theta} \frac{C^{\prime}}{C_{1}}
$$

where $B$ is the blank in metres ( $1.76 \mathrm{~m}$ for all deployments), $L$ is the transmit pulse length in metres, $D$ is the depth cell length in metres ( $8 \mathrm{~m}$ for all deployments), $n$ is the depth cell number of the scattering layer being measured, $\theta$ is the beam angle in degrees $\left(20^{\circ}\right), C_{1}$ is the speed of sound in the water used by the ADCP (set to $1475.1 \mathrm{~m} \mathrm{~s}^{-1}$ ), while $C^{\prime}$ is the average sound speed from the transducer to the range cell that depends on the depth (computed by means of Mackenzie formula; (MacKenzie, 1981)) using the same MED6 data previously extracted and interpolated at a vertical resolution of $1 \mathrm{~m}$ from 0 up to $100 \mathrm{~m}$. To be used in Eq. (1), the slant range should not be less than $\pi R_{0} / 4$, where $R_{0}$ is the Rayleigh distance defined by RDI for the Workhorse Sentinel $300 \mathrm{kHz}$ ADCP as $0.98 \mathrm{~m}$. According to Gordon (1996), the maximum range of acceptable data $R_{\max }$ should satisfy Eq. (4):

$R_{\max }=H \cos \theta$,

where $H$ is the distance of the instrument to the surface. In all three deployments both requirements were satisfied. The backscatter strength value $S v$ was obtained by averaging the results of Eq. (1) applied to the four available beams. The averaged Sv profiles for the three deployments at different depths are shown in Fig. 3. The results show that these values can be influenced by a low signal to noise ratio, as pointed out by Gostiaux and van Haren (2010), who suggest modifying Eq. (1) as

$$
\begin{aligned}
\mathrm{Sv}= & 20 \log _{10}(R)+2 \alpha R-A \\
& +10 \log _{10}\left(10^{K_{\mathrm{c}} E / 10}-10^{K_{\mathrm{c}} E_{\mathrm{r}} / 10}\right)
\end{aligned}
$$

and introducing the ADCP transmit lag $L_{a}$ in Eq. (3), thus obtaining Eq. (6):

$R=\frac{B+\left(\frac{L+D+L_{a}}{2}\right)+[(n-1) D]+\frac{D}{4}}{\cos \theta}$.

In order to determine the constant $A$, a best linear fit between the Sv values obtained by the Gostiaux and van Haren

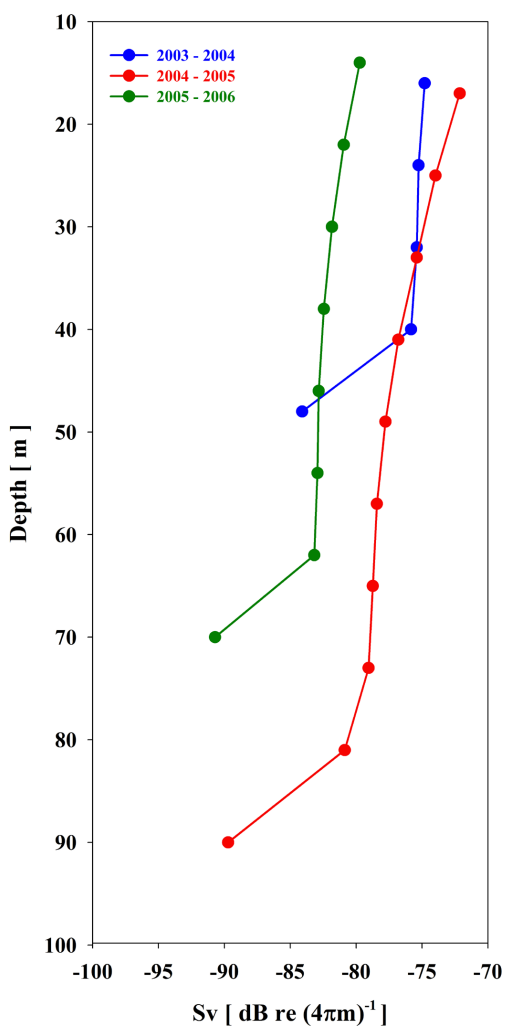

Fig. 3. Average backscatter strength profiles for the three deployments.

equation and the Sv values calculated by the Deines formula is performed using only the bins that satisfy the test $K_{\mathrm{c}}\left(E-E_{\mathrm{r}}\right)>10$. In the 2003-2004 data set, the signal to noise ratio is very high for almost all acquired data, so that the improvement of the Gastiaux and van Haren equation is limited to a quite constant little shift for all layers. On the contrary, in the 2004-2005 data set, the differences between the backscattering strength values computed using the two methods increase with the increasing of the slant range. These differences become more marked for the data acquired in the third deployment, while disagreement is also found for the first two bins.

Furthermore, the closest bin to the transducer is characterized by a very weak signal and consequently the ADCP profile shows a high gradient on the second bin: this behaviour is due to the transient time needed by the instrument to transmit and receive the signal, thus during this gap of time the acquired data can be erroneous (Lane et al., 1999).

Taking into account the previous issues, the used $\mathrm{Sv}$ values have been computed using Eq. (5), discarding the bin closest to the transducer, as well as the one closest to the sea surface since it may be strongly affected by the atmosphere (Schott, 1989). 

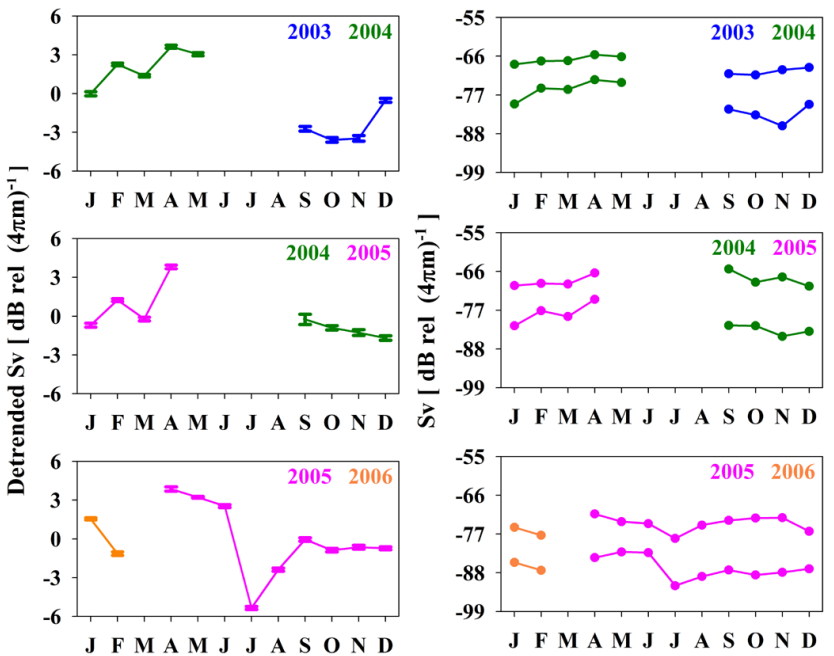

Fig. 4. Backscatter strength at $40 \mathrm{~m}$ depth during the three deployments: (left) detrended monthly averaged time series with error bars corresponding to uncertainties in the average estimation; (right) monthly maximum- and minimum values. Data from year 2003 in blue, 2004 in green, 2005 in pink, and 2006 in orange. Time axis aligned from January to December.

\section{Results}

\subsection{Seasonal variability}

The monthly mean backscattering strength values computed for each time series at the common depth of about $40 \mathrm{~m}$ are shown in Fig. 4. Although none of the time series covers an entire year and not all months are complete, the three distributions show similar seasonal behaviour with an increase in spring and lower values during the fall months. A relative maximum is also detected in January-February, while an abrupt drop, with very low values, is recorded in July 2005.

The seasonal NPP values show a pronounced interannual variability (Fig. 5). In 2003 the mean annual NPP cycle is characterized by two peaks: the major one in April $\left(707 \mathrm{mg} \mathrm{C} / \mathrm{m}^{2}\right.$ day $\left.^{-1}\right)$ and the other in November $\left(481 \mathrm{mg} \mathrm{C} / \mathrm{m}^{2} \mathrm{day}^{-1}\right)$. In 2004 there is a unique peak of NPP from March to May (mean NPP = $706 \pm 70 \mathrm{mg} \mathrm{C} / \mathrm{m}^{2} \mathrm{day}^{-1}$ ), while in 2005 an extraordinarily high NPP peak is recorded from April (1221 mg C/m $\mathrm{may}^{-1}$ ) to May ( $1070 \mathrm{mg} \mathrm{C} / \mathrm{m}^{2} \mathrm{day}^{-1}$ ), but high NPP values persist until August (on average $547 \pm 42 \mathrm{mg} \mathrm{C} / \mathrm{m}^{2}$ day $^{-1}$ ).

The pattern of backscattering strength values is consistent with NPP trends with an expected delay of about 1 month between the peak of surface primary production and the response by the zooplankton community. Indeed, the peak of zooplankton biomass is recorded in April-May (Fig. 4) after the peak of NPP in March-April (Fig. 5).

In Fig. 4, apart from the generally high values observed from April to June (common to the three deployments), which are consistent with the main peak of NPP in temperate

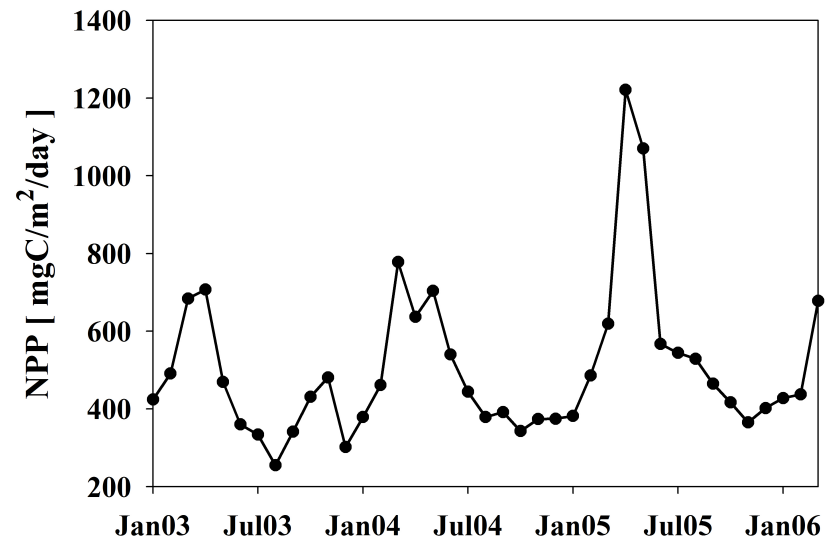

Fig. 5. Monthly averaged net primary production values recorded in the study area during the sampling period.

areas, the second greatest value for the third deployment occurred in January 2006. This fully agrees with the increase in NPP values recorded in December 2005 and the recognized delay between phytoplankton production and the successive zooplankton biomass increase, as previously explained. On the other hand the low Sv value found in July 2005, the only year in which this period was examined, was in agreement with the almost complete disappearance of Meganyctiphanes norvegica from the upper water layers, as observed by Andersen (2001b) in June in the western Ligurian Sea. This species goes deeper at the end of its reproductive season (end of spring) and lives at $500 \mathrm{~m}$ and even $1000 \mathrm{~m}$, being the deepest sampled species (Franqueville, 1971; Sardou and Andersen, 1996). In addition, Huntley and Brooks (1982) reported that when food is scarce in the surface waters, the usual DVM performers cease vertical migration until food concentrations suffice to support it and this likely occurs in July, far from the peak of NPP in surface, when food availability is low.

The observed ADCP time series is also in agreement, in terms of seasonal dynamic, with the distribution of monthly mean Continuous Plankton Recorder (CPR) data collected in the northwestern Mediterranean Sea in the period 1977 1999 (Licandro and Icardi, 2009). This ADCP time series is substantially uniform down the water column, at least to $30 \mathrm{~m}$ depth, while a greater variability is noted below this depth and between the ADCP time series of the three deployments.

\subsection{Daily mean cycle}

The first experiment starts at the end of the anomalous warm summer 2003 and the measures are limited to the upper $50 \mathrm{~m}$ of the sea. From the beginning of the observational period in September 2003 to the first half of October, the mean daily backscatter strength values are high, particularly in the layers above $30 \mathrm{~m}$ depth (Fig. 6). Starting from mid-October until the first days of December 2003, with the exception 


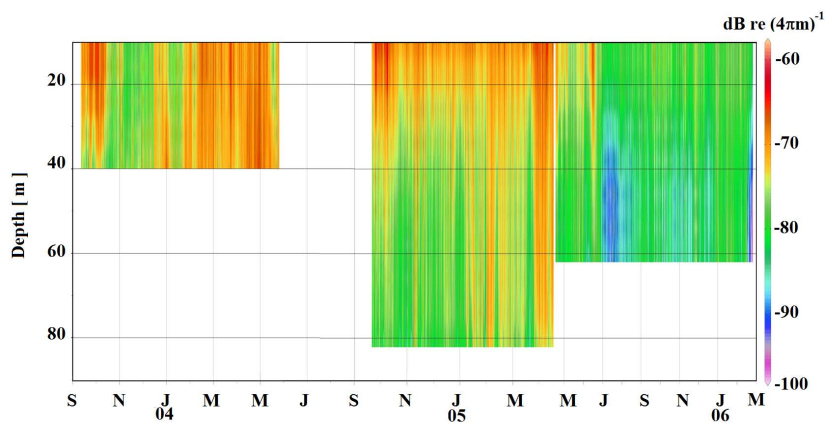

Fig. 6. Time series of daily mean backscatter strength data recorded during the three deployments. Year is indicated below January label.

of early November, they undergo a significant decrease and slightly higher values are recorded only sporadically below $30 \mathrm{~m}$. From mid-December 2003, the signal begins to grow and the whole observed water column becomes substantially homogeneous. From mid-April the measured values are again high, even if only on a few occasions, reaching those recorded in October. A weak reduction appears in the surface layer shortly before the recovery of the mooring at the end of May 2004.

The mooring configuration adopted in the second experiment allows investigation down to $80 \mathrm{~m}$ depth. The mean daily backscatter strength data collected above $35 \mathrm{~m}$ depth show a trend similar to the one of the previous period 20032004: starting from mid-October 2004 the values decrease until December, when they start to grow slowly again to reach (after a short period of attenuation in March 2005) the highest values in April. However, in the upper $30 \mathrm{~m}$ layers the $\mathrm{Sv}$ values remain high the whole time and the homogenization of the examined water column occurs only sporadically below $25 \mathrm{~m}$ depth until January 2005, when strong signals begin to be registered even in the deepest layers. At the end of March, after a short period of decrease, which affects the water column up to almost the surface, the Sv values are large at all depths.

Summer data are available only for the third experiment, in a long period of exceptionally calm conditions of both marine and atmospheric dynamics. From mid-June to the end of August the recorded Sv values are very small, especially below $30 \mathrm{~m}$ depth. A significant reduction of total zooplankton biomass in the summer months is also shown in the CPR data (Licandro and Icardi, 2009). However, except for a few events of short duration, the mean daily backscatter remains weak until mid-February, when a significant further drop is observed just before the end of the measurements.

Despite the significant inter-annual differences, a fairly constant characteristic in the time series of the monthly mean hourly Sv data is the presence of a marked daily cycle, with low values during the daylight and high ones in the night (Fig. 7). In correspondence with the sudden changes in the Sv signal, negative peaks in the early morning and positive
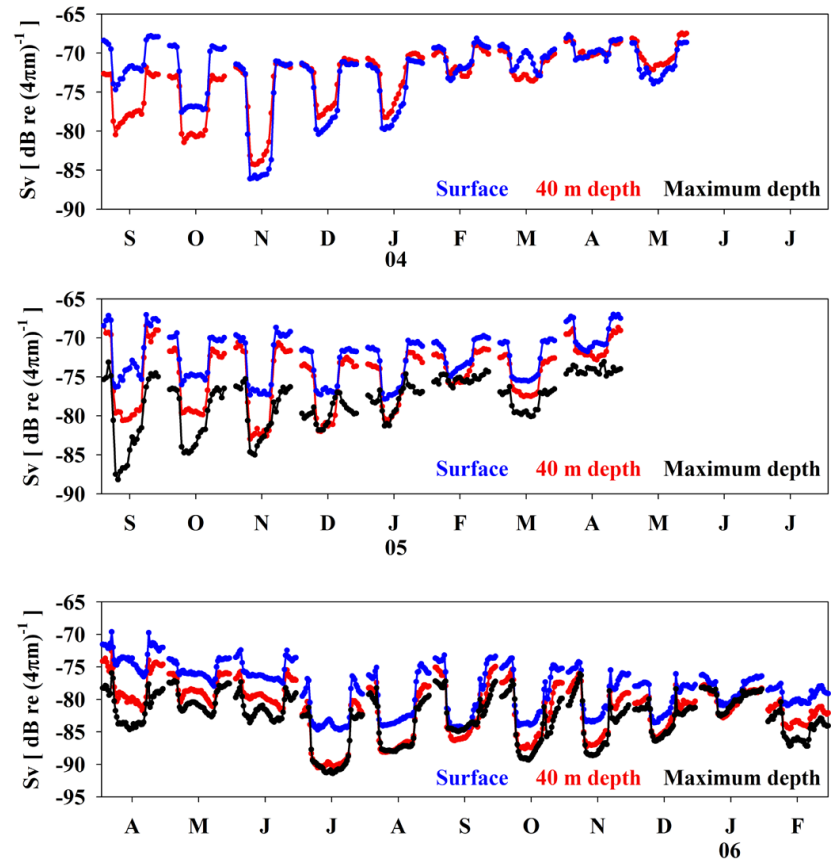

Fig. 7. Monthly mean daily cycle of backscatter strength values at different depths. Year is indicated below January label.

ones in the afternoon are found in the monthly time series of the vertical velocity mean hourly values (Fig. 8).

A noteworthy agreement results between the time of sunrise and sunset at the mooring position, and the time at which the lowest and highest daily values of both vertical velocity and Sv hourly changes occur, especially for the third period when the used sampling time is set at $30 \mathrm{~min}$. It should be noted that significant values of vertical velocity are recorded almost exclusively for a short time around dusk and dawn. This characteristic suggests that these velocities are related mainly to displacements of the scatter elements rather than to vertical motions of the water masses.

\subsection{Diel vertical migration}

Results mentioned above can be ascribed to the diel vertical migration performed by several species of the zooplankton population. This is a vertical movement, generally involving a $24 \mathrm{~h}$ cycle, the causes of which are not yet fully understood (Ringelberg, 2010). Three main patterns have been identified: "normal" or "nocturnal" DVM involves animals moving deeper in the water column during the day and shallower at night. A less common behaviour is exhibited by a slow descent following arrival at the surface at dusk, and a subsequent second ascent to the surface towards the end of the night, prior to the dawn descent ("twilight migration"). Other species or live stages undergo "reverse migration", where the zooplankton ascend at dawn and descend at dusk (Heywood, 1996; Jiang et al., 2007; Cisewski et al., 2010). 

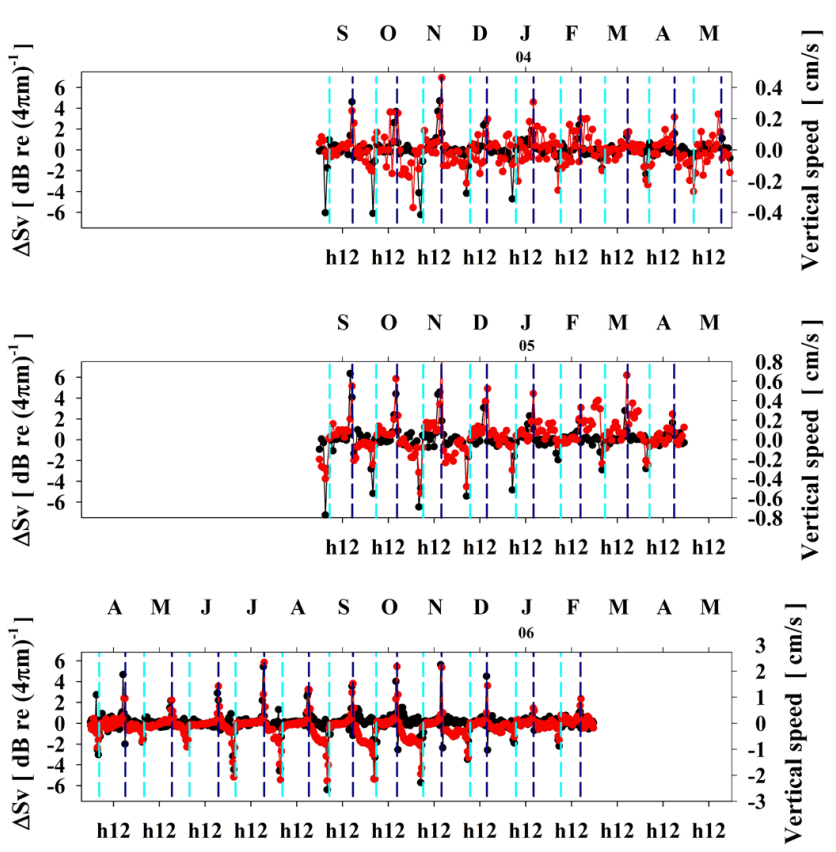

Fig. 8. Monthly mean daily cycle of temporal derivative of backscatter strength and vertical speed at $40 \mathrm{~m}$ depth for the three deployments: (top) 2003-2004, (middle) 2004-2005, and (bottom) 2005-2006. Vertical dashed lines correspond to hour of sunrise (cyan) and sunset (blue) of each month. Time axis aligned from April of one year to May of the following year. Year is indicated below January label.

The backscatter strength shows significant differences both in time and with depth. To better investigate these patterns, two different data sets for each experiment are obtained, separating the observations taken between sunrise and sunset (Fig. 9, on the left) from those collected between sunset and sunrise (Fig. 9, on the right).

During the first experiment, the measured data show a quite uniform vertical distribution of the backscattering strength. These values are for most of the examined period rather large during both day and night. Only in two periods, between October and December 2003 and for a few days in January 2004, the diurnal values undergo a significant reduction, denoting fewer scatter organisms during daylight. In the second and third experiments, such small values are never observed above $30 \mathrm{~m}$ depth. In this upper layer the backscatter strength signal remains large with small differences between day and night. Below $40 \mathrm{~m}$ depth a strong reduction is often observed during daylight, while in the night the signal increases and has a tendency to homogenize the whole observed water column.

\subsection{Spectral analysis}

The spectral analysis performed on the three time series at the shared depth of $40 \mathrm{~m}$ does not differ significantly among samples. It is characterized by a dominant $24 \mathrm{~h}$ peak and
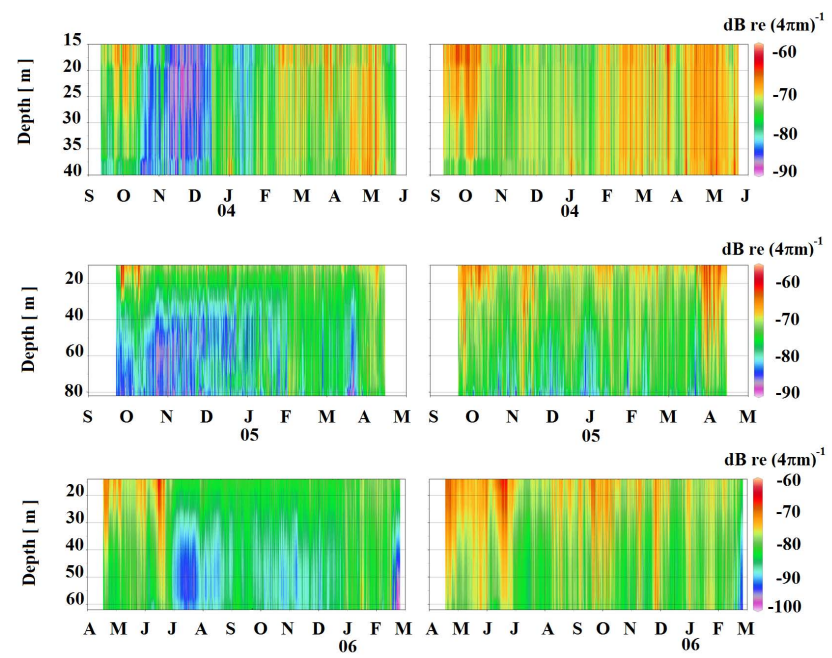

Fig. 9. Time series of backscatter strength profile for data collected (left) between sunrise and sunset and (right) between sunset and sunrise in the three deployments. Year is indicated below January label.

a series of minor peaks at the higher harmonics. It confirms the predominance of a signal with a $24 \mathrm{~h}$ cycle corresponding to the so-called "normal" or "nocturnal" pattern (Fig. 10). The secondary $12 \mathrm{~h}$ peak may be attributable to a different DVM pattern, the so-called twilight migration (Cushing, 1951).This is sometimes distinguished in the hourly $\mathrm{Sv}$ values, especially during the third experiment that has $30 \mathrm{~min}$ temporal resolution (Fig. 11). Twilight migrations were found in more than $80 \%$ of records of northwestern Atlantic zooplankton DVM (Ashjian et al., 1994). The observed behavioural patterns have different interpretations, with hunger-satiation and escapes from predators (i.e. krill) as the most plausible causes (Tarling et al., 1999).

Time-frequency analysis provides evidence for the temporal evolution of the amplitude of each signal and allows for the identification of the periods when a signal characterizing a specific DVM pattern is prevailing. The spectrograms are obtained using a $240 \mathrm{~h}$ sliding window with $216 \mathrm{~h}$ overlap between each sample. For all three periods, the time evolution of the amplitude of the $12 \mathrm{~h}$ and $24 \mathrm{~h}$ harmonics at different depths is given in Fig. 12.

The three distributions show that both $12 \mathrm{~h}$ and $24 \mathrm{~h}$ cycles are particularly intense between November and December, when the backscattering strength values are least. Furthermore, during the first experiment the maximum of the spectrum for the $24 \mathrm{~h}$ harmonic is obtained for the surface layer, and it is found at $40 \mathrm{~m}$ depth for the $12 \mathrm{~h}$ harmonic. On the contrary, during the other two experiments, the spectrum for both harmonics is weak at the surface. The $24 \mathrm{~h}$ harmonic time series shows the maximum amplitude at $40 \mathrm{~m}$ depth, while the $12 \mathrm{~h}$ harmonic shows it at the deepest layers.

These results may suggest the presence of different types of zooplankton organisms, some of which migrate according 


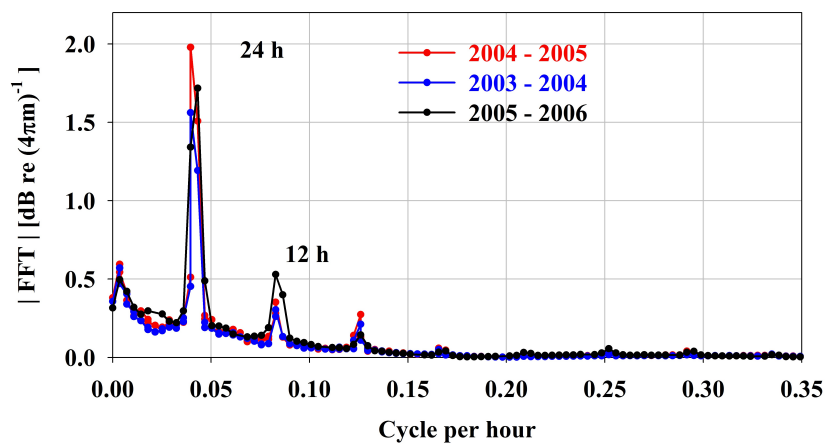

Fig. 10. Power spectrum for the three times series of the backscatter strength at $40 \mathrm{~m}$ depth.

to their own specific DVM pattern, while others are stationary, as observed in other areas like in the Irish Sea where generally more than $60 \%$ of the zooplankton community does not perform significant DVM (Irigoien et al., 2004). In the Mediterranean Sea few mesozooplanktonic species show considerable DVM. Thus, taking into account that the widest migrations appear when the backscatter is weak, the more marked DVM signals may be ascribed to some large and more active organisms, likely macrozooplankton and micronekton (i.e. euphausiids, small mesopelagic fish) which are quite abundant in late autumn in other areas of the northwestern Mediterranean (McGehee et al., 2004; Olivar et al., 2012). Among them, the euphausiid Meganyctiphanes norvegica is one of the most widespread in the Ligurian Sea (Tarling et al., 2001; Andersen, 2001a). Its vertical migration is usually wide and has a $24 \mathrm{~h}$ cycle, however, depending on multiple factors (i.e. reproduction, moon phase, etc.), it can also take place on a $12 \mathrm{~h}$ cycle.

\subsection{Vertical velocities analysis}

Data obtained by ADCP are considered to be an average of a backscattering field consisting of both migrating and stationary organisms (Plueddemann and Pinkel, 1989). Depending on the prevalence of one or another organism, the DVM signal may be more or less detectable by ADCP measurements. Each migrating species has its own behaviour that may change during the different stages of life and due to environmental conditions. Different studies provided accurate estimates of vertical velocity of zooplankton population, which generally varied (depending on the frequency used for the estimates) between 1 and $8 \mathrm{~cm} \mathrm{~s}^{-1}$. Vertical velocity is greater during ascent $\left(5-8 \mathrm{~cm} \mathrm{~s}^{-1}\right)$ than during descent (3$4 \mathrm{~cm} \mathrm{~s}^{-1}$ ) and with increasing depth (Heywood, 1996; Smith et al., 2008).

Although the ADCP measurements do not give the true value of the zooplankton vertical speed but, generally, a lesser one (Plueddemann and Pinkel, 1989; Tarling et al., 2001), the analysis of the recorded mean hourly vertical velocity may help to investigate if part of the observed
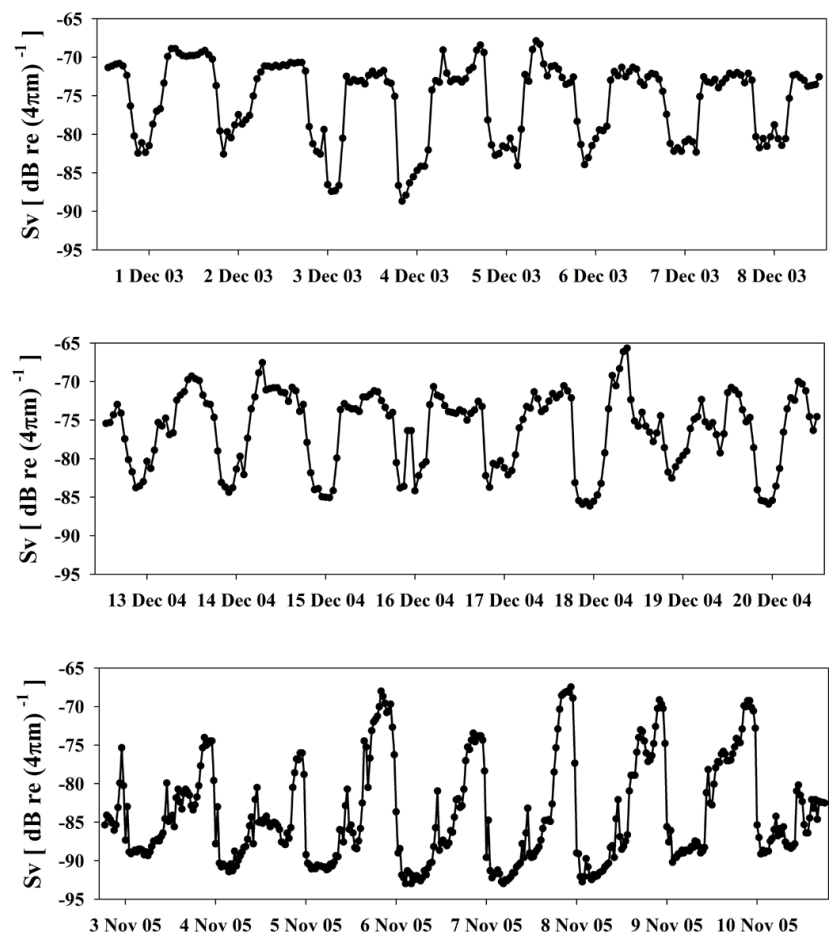

Fig. 11. Subset of backscatter strength hourly data at $40 \mathrm{~m}$ depth in presence of twilight diel vertical migration pattern for the three deployments. Label at 12:00 UTC.

variability could be ascribed to a change of the proportion between the different genotypes making up the observed zooplankton population.

Almost all vertical velocity data have values close to zero. Values greater than $\pm 0.5 \mathrm{~cm} \mathrm{~s}^{-1}$ are recorded mainly in conjunction with changes of $\mathrm{Sv}$ or during strong wind events.

As a result, the analysis is carried out on the time series of the maximum and minimum daily values (Fig. 13). The time series of maximum and minimum mean hourly vertical velocity show that values tend to increase from the first to the third experiment and going from the surface to the deepest layers. In fact, during the first deployment more than $94 \%$ of the values are between $\pm 1.5 \mathrm{~cm} \mathrm{~s}^{-1}$, of which $40 \%$ fall in the range $\pm 0.5 \mathrm{~cm} \mathrm{~s}^{-1}$. During the second deployment, the percentage in the range $\pm 1.5 \mathrm{~cm} \mathrm{~s}^{-1}$ is still greater than $90 \%$, but far fewer values are between $\pm 0.5 \mathrm{~cm} \mathrm{~s}^{-1}$ and the decrease is even more evident in the deepest layer, where they are less than $10 \%$. During the third deployment the recorded values are larger at all depths and fewer than $10 \%$ are in the interval $\pm 0.5 \mathrm{~cm} \mathrm{~s}^{-1}$.

Although during the first experiment the extreme values of the vertical velocity are small, the analysis of the daily data shows that, under strong wind conditions lasting a few days, peaks of up to $5 \mathrm{~cm} \mathrm{~s}^{-1}$ and more are recorded, mainly in the surface layer whilst they decrease with depth. These large values are never reached in the other two periods, despite the occurrence of several episodes with even stronger 

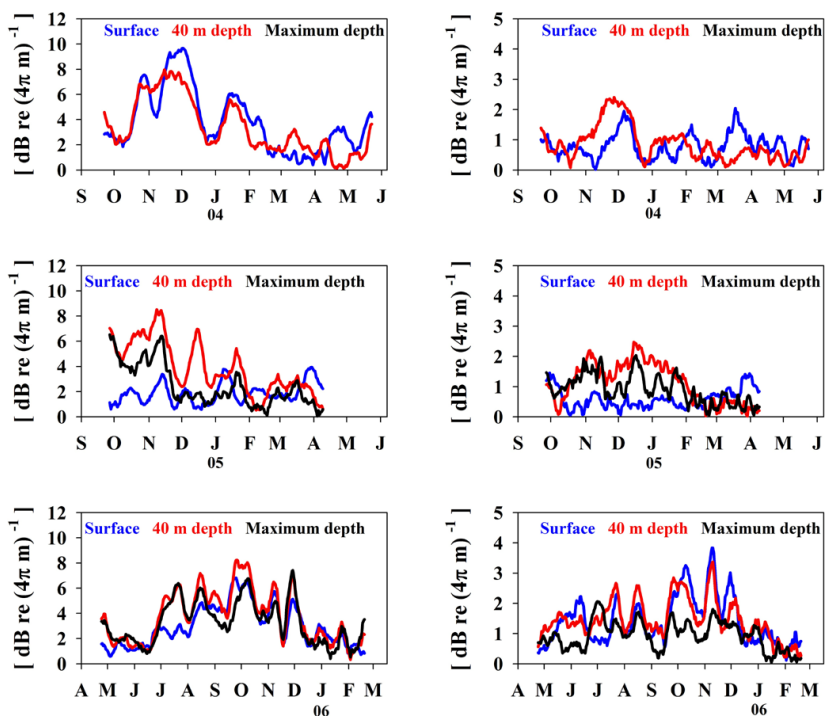

Fig. 12. (left) Time evolution of the amplitude of the $24 \mathrm{~h}$ and (right) $12 \mathrm{~h}$ harmonics at different depths. Year is indicated below January label.

wind. Furthermore, the first period is also characterized by a different distribution of the vertical velocities. This does not show any particular seasonal pattern, but rather single episodes whose amplitude is less in spring. On the contrary, a weak seasonal trend may be detected for the data collected during the second and third periods. Particularly, the extreme values of the vertical velocity increase from late summer to November, when they start again to decrease, reaching minimum values in January. During the period 2005-2006, an increase and subsequent decrease is also observed between the middle of June and the end of August.

\section{Discussion and conclusions}

Three years of acoustic backscatter and vertical velocities data collected by a $300 \mathrm{kHz}$ ADCP in the central Ligurian Sea are analysed to investigate the zooplankton dynamics. Even based on only one frequency and without net samples, the analysis of backscatter variability at different timescales allows for the identification of different zooplankton migration patterns and, from these, to infer about its presence and composition in the area.

At seasonal scale, the biomass follows the NPP signal with a delay of about 1 month, having higher values in April and May and a secondary maximum in January or February; lower values are generally observed in autumn.

The prevailing vertical migration pattern is the $24 \mathrm{~h}$ cycle performed by the zooplankton swimming upward at sunset and downward at sunrise. A second pattern having a $12 \mathrm{~h}$ cycle is also identified, the twilight migration, in particular in the measurements with 30 min temporal resolution.
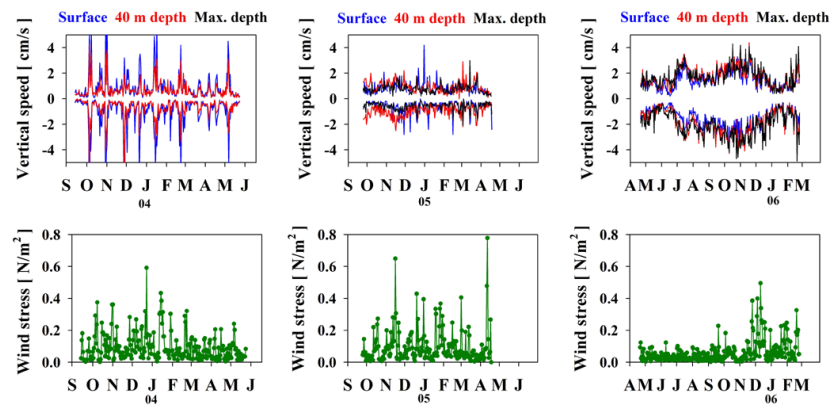

Fig. 13. (upper panel) Maximum and minimum vertical velocity and (lower panel) wind stress at different depths. Year is indicated below January label.

Furthermore, the analysis of both Sv and vertical velocity data suggests that changes in composition of zooplankton population may occur during the three years of continuous monitoring.

Although no biological sampling was performed during the experiments, the results of several studies made in adjacent areas (Licandro and Ibanez, 2000) and the zooplankton composition there reported can help in interpreting the findings of this ADCP data analysis. Among the mesozooplanktonic species abundantly found in those studies, such as Clausocalanus spp., Paracalanus spp. and Oithona spp. (McGehee et al., 2004; Licandro and Ibanez, 2000), no one species shows a strong diel vertical migration (Andersen, 2001b). Indeed, according to Brugnano et al. (2011), only species of the Scolecithricidae family show significant DVM in the area, confirming previous information about the presence of a few strong migrants in the Mediterranean Sea. Thus, it may be supposed that the species mainly responsible for the strong Sv signal found in some periods of this study, at times of small biomass, are ascribable to the macroplanktonic/micronektonic component. Particularly, the area is dominated by the euphausiid Meganyctiphanes norvegica (Tarling et al., 2001; Andersen, 2001a) which attains its maximum abundance values in August-September. This species is known to perform wide vertical migration (Kaartvedt, 2010) and it could be responsible for the maximum amplitude found in ADCP data recorded in September 2005 .

Furthermore, other previous investigations (Boucher et al., 1987; Licandro and Ibanez, 2000; McGehee et al., 2004; de Puelles and Molinero, 2008; Raybaud et al., 2008; Licandro and Icardi, 2009) point out that the Ligurian Sea is characterized by different zooplankton populations whose distribution is related to the main hydrological features of this basin. The importance of Mediterranean circulation dynamics in the determination of different zooplankton associations was also found in the Gulf of Trieste (Cataletto, 1995) and in the Gulf of Naples (Carrada et al., 1980). 
Water masses and marine circulation of the whole Mediterranean Sea, and particularly of the Ligurian Basin, underwent major changes over the three years of the study. The contemporaneous measurements of sea currents show a significant modification in the study area, with an anticlockwise rotation from north to west and a decrease of intensity (Fig. 2). This may lead to the dominance of different zooplankton associations, related to changes in current intensity and direction, as observed by Licandro and Ibanez (2000) in a long-term study in the Gulf of Tigullio, an area adjacent to the ADCP mooring position.

Although more qualitative than quantitative, the results of this study clearly show the skill of ADCP to highlight some characteristics of the zooplankton population that the usual biological observations hardly fail to grasp. Particularly, they show the important role of the time at which the discrete biological sampling is carried out. Thus, in the future, the joint use of long-term continuous monitoring by ADCP and periodic net samplings may be a good observational strategy for deepening the zooplankton knowledge. Nevertheless, at present, the re-examination of backscatter signals of many long time series of ADCP data that have been collected to estimate horizontal and vertical oceanic currents can also contribute to the biological monitoring of the oceans, even in the absence of corresponding in situ direct observations.

Acknowledgements. The work has been partially supported by the Flagship Project RITMARE - The Italian Research for the Sea - coordinated by the National Research Council of Italy and funded by the Italian Ministry of Education, University and Research within the National Research Program 2011-2013 and by the Italian National Program of Antarctic Research (PNRA) under grant 2010/A4.01. The authors acknowledge the ECMWF organization for providing the ERA-Interim data used in this study and Stefano Salon from OGS (Trieste, Italy) for providing the climatological sound speed profiles.

Edited by: J. M. Huthnance

\section{References}

Ainslie, M. A.: A simplified formula for viscous and chemical absorption in sea water, J. Acoust. Soc. Am., 103, 1671-1672, 1998.

Andersen, V.: Zooplankton Community During the Transition from Spring Bloom to Oligotrophy in the Open NW Mediterranean and Effects of Wind Events. 1. Abundance and Specific Composition, J. Plankton Res., 23, 227-242, 2001a.

Andersen, V.: Zooplankton Community During the Transition from Spring Bloom to Oligotrophy in the Open NW Mediterranean and Effects of Wind Events. 2. Vertical Distributions and Migrations, J. Plankton Res., 23, 243-261, 2001b.

Andersen, V. and Sardou, J.: The diel migrations and vertical distributions of zooplankton and micronekton in the Northwestern Mediterranean Sea. 1. Euphausiids, mysids, decapods and fishes, J. Plankton Res., 14, 1129-1154, 1992.
Ashjian, C. J., Smith, S. L., Flagg, C. N., Mariano, A. J., and Beherens, W. J.: The influence of a Gulf Stream meander on the distribution of zooplankton biomass in the Slope Water, the Gulf Stream, and the Sargasso Sea, described using a shipboard acoustic Doppler current profiler, Deep Sea Res.-Pt. I, 41, 23-50, 1994.

Ashjian, C. J., Smith, S. L., Flagg, C. N., and Idrisi, N.: Distribution, annual cycle, and vertical migration of acoustically derived biomass in the Arabian Sea during 1994-1995, Deep Sea Res.Pt. II, 49, 2377-2402, 2002.

Astraldi, M. and Gasparini, G. P.: The seasonal characteristics of the circulation in the north Mediterranean basin and their relationship with the atmospheric-climatic conditions, J. Geophys. Res., 97, 9531-9540, 1992.

Behrenfeld, M. J. and Falkowski, P. G.: Photosynthetic rates derived from satellite-based chlorophyll concentration, Limnol. Oceanogr., 42, 1-20, 1997.

Birol, F., Cancet, M., and Estournel, C.: Aspects of the seasonal variability of the Northern Current (NW Mediterranean Sea) observed by altimetry, J. Marine Syst., 81, 297-311, 2010.

Boucher, J., Ibanez, F., and Prieur, L.: Daily and seasonal variations in the spatial distribution of zooplankton populations in relation to the physical structure in the Ligurian Sea Front, J. Marine Res., 45, 133-173, 1987.

Brankart, J.-M. and Pinardi, N.: Abrupt Cooling of the Mediterranean Levantine Intermediate Water at the Beginning of the 1980s: Observational Evidence and Model Simulation, J. Phys. Oceanogr., 31, 2307-2320, 2001.

Brugnano, C., D’Adamo, R., Fabbrocini, A., Granata, A., and Zagami, G.: Zooplankton responses to hydrological and trophic variability in a Mediterranean coastal ecosystem (Lesina Lagoon, South Adriatic Sea), Chem. Ecol., 27, 461-480, 2011.

Carrada, G. C., Hopkins, T. S., Bonaduce, G., Ianora, A., Marino, D., Modigh, M., Ribera, D. M., and Scotto, C. B.: Variability in the Hydrographic and Biological Features of the Gulf of Naples, Mar. Ecol., 1, 105-120, 1980.

Cataletto, B.: Eleven years of time-series analysis on the netzooplankton community in the Gulf of Trieste, Ices J. Mar. Sci., 52, 669-678, 1995.

Cisewski, B., Strass, V. H., Rhein, M., and Krägefsky, S.: Seasonal variation of diel vertical migration of zooplankton from ADCP backscatter time series data in the Lazarev Sea, Antarctica, Deep Sea Res.-Pt. I, 57, 78-94, 2010.

Crepon, M., Wald, L., and Monget, J. M.: Low-frequency waves in the Ligurian Sea during December 1977, J. Geophys. Res., 87, 595-601, 1982.

Cushing, D. H.: The vertical migration of planktonic crustacea, Biol. Rev., 26, 158-192, 1951.

de Puelles, M. L. F. and Molinero, J. C.: Decadal changes in hydrographic and ecological time-series in the Balearic Sea (western Mediterranean), identifying links between climate and zooplankton, Ices J. Mar. Sci., 65, 311-317, 2008.

Dee, D. P., Uppala, S. M., Simmons, A. J., Berrisford, P., Poli, P., Kobayashi, S., Andrae, U., Balmaseda, M. A., Balsamo, G., Bauer, P., Bechtold, P., Beljaars, A. C. M., van de Berg, L., Bidlot, J., Bormann, N., Delsol, C., Dragani, R., Fuentes, M., Geer, A. J., Haimberger, L., Healy, S. B., Hersbach, H., Hólm, E. V., Isaksen, L., Kållberg, P., Köhler, M., Matricardi, M., McNally, A. P., Monge-Sanz, B. M., Morcrette, J.-J., Park, B.-K., Peubey, C., de Rosnay, P., Tavolato, C., Thépaut, J.-N., and Vitart, F.: The 
ERA-Interim reanalysis: configuration and performance of the data assimilation system, Q. J. Roy. Meteorol. Soc., 137, 553597, 2011.

Deines, K. L.: Backscatter estimation using Broadband acoustic Doppler current profilers, in: Working Conference on Current Measurement, 1999.

di Carlo, B., Ianora, A., Fresi, E., and Hure, J.: Vertical zonation patterns for Mediterranean copepods from the surface to $3000 \mathrm{~m}$ at a fixed station in the Tyrrhenian Sea, J. Plankton Res., 6, 10311056, 1984

Fanelli, E., Cartes, J. E., Rumolo, P., and Sprovieri, M.: Foodweb structure and trophodynamics of mesopelagic-suprabenthic bathyal macrofauna of the Algerian Basin based on stable isotopes of carbon and nitrogen, Deep Sea Res.-Pt. I, 56, 1504$1520,2009$.

Fielding, S., Griffiths, G., and Roe, H. S. J.: The biological validation of ADCP acoustic backscatter through direct comparison with net samples and model predictions based on acousticscattering models, Ices J. Mar. Sci., 61, 184-200, 2004.

Flagg, C. and Smith, S.: On the use of the acoustic Doppler current profiler to measure zooplankton abundance, Deep Sea Res.-Pt. A, 36, 455-474, 1989.

Font, J., Puig, P., Salat, J., Palanques, A., and Emelianov, M.: Sequence of hydrographic changes in NW Mediterranean deep water due to the exceptional winter of 2005, Sci. Mar., 71, 339-346, 2007.

Franqueville, C.: Macroplancton profond (Invertébrés) de la Méditerranée nord-occidentale, Tethys, 3, 11-56, 1971.

Furnestin, M. L.: Zooplancton du Golfe du Lion et de la côte orientale de Corse, Rev. Trav. Inst. Pêches Marit., 24, 153-252, 1960.

Garrabou, J., Coma, R., Bensoussan, N., Bally, M., Chevaldonné, P., Cigliano, M., Diaz, D., Harmelin, J., Gambi, M., Kersting, D., Ledoux, J., Lejeusne, C., Linares, C., Marschal, C., Pérez, T., Ribes, M., Romano, J., Serrano, E., Teixido, N., Torrents, O., Zabala, M., Zuberer, F., and Cerrano, C.: Mass mortality in Northwestern Mediterranean rocky benthic communities: Effects of the 2003 heat wave, Glob. Change Biol., 15, 1090-1103, 2009.

Gordon, R.: Acoustic Doppler Current Profilers Principles of Operation: A Practical Primer, RD Instruments, 1996.

Gostiaux, L. and van Haren, H.: Extracting Meaningful Information from Uncalibrated Backscattered Echo Intensity Data, J. Atmos. Ocean. Tech., 27, 943-949, 2010.

Hays, G. C.: A review of the adaptive significance and ecosystem consequences of zooplankton diel vertical migrations, Hydrobiologia, 503, 163-170, 2003.

Heywood, K. J.: Diel vertical migration of zooplankton in the Northeast Atlantic, J. Plankton Res., 18, 163-184, 1996.

Huntley, M. and Brooks, E.: Effects of age and food availability on diel vertical migration of Calanus pacificus, Mar. Biol., 71, 2331, 1982.

Irigoien, X., Conway, D., and Harris, R.: Flexible diel vertical migration behaviour of zooplankton in the Irish Sea, Marine Ecology-progress Series, 267, 85-97, 2004.

Jiang, S., Dickey, T. D., Steinberg, D. K., and Madin, L. P.: Temporal variability of zooplankton biomass from ADCP backscatter time series data at the Bermuda Testbed Mooring site, Deep Sea Res.-Pt. I, 54, 608-636, 2007.
Kaartvedt, S.: Diel Vertical Migration Behaviour of the Northern Krill (Meganyctiphanes norvegica Sars), Vol. 57, 255-275, doi:10.1016/B978-0-12-381308-4.00009-1, 2010.

Lane, A., Knight, P. J., and Player, R. J.: Current measurement technology for near-shore waters, Coast. Eng., 37, 343-368, 1999.

Licandro, P. and Ibanez, F.: Changes of zooplankton communities in the Gulf of Tigullio (Ligurian Sea, Western Mediterranean) from 1985 to 1995 . Influence of hydroclimatic factors, J. Plankton Res., 22, 2225-2253, 2000.

Licandro, P. and Icardi, P.: Basin scale distribution of zooplankton in the Ligurian Sea (north-western Mediterranean) in late autumn, Hydrobiologia, 617, 17-40, 2009.

MacKenzie, K. V.: Nine-term equation for sound speed in the oceans, J. Acoust. Soc. Am., 70, 807-812, 1981.

Margalef, R.: Environmental Control of the Mesoscale Distribution of Primary Producers and Its Bearing to Primary Production in the Western Mediterranean, Plenum Press, 1985.

Martín, J., Miquel, J.-C., and Khripounoff, A.: Impact of open sea deep convection on sediment remobilization in the western Mediterranean, Geophys. Res. Lett., 37, L13604, doi:10.1029/2010GL043704, 2010.

Mazzocchi, M. G., Christou, E. D., Capua, I. D., de Puelles, M. F., Fonda-Umani, S., Molinero, J. C., Nival, P., and Siokou-Frangou, I.: Temporal variability of Centropages typicus in the Mediterranean Sea over seasonal-to-decadal scales, Prog. Oceanogr., 72, 214-232, 2007.

McGehee, D., Demer, D., and Warren, J.: Zooplankton in the Ligurian Sea: Part I. Characterization of their dispersion, relative abundance and environment during summer 1999, J. Plankton Res., 26, 1409-1418, 2004.

Millot, C.: Circulation in the Western Mediterranean Sea, J. Mar. Syst., 20, 423-442, 1999.

Olivar, M., Bernal, A., Molí, B., na, M. P., Balbín, R., Castellón, A., Miquel, J., and Massutí, E.: Vertical distribution, diversity and assemblages of mesopelagic fishes in the western Mediterranean, Deep Sea Res.-Pt. I, 62, 53-69, 2012.

Picco, P., Cappelletti, A., Sparnocchia, S., Schiano, M. E., Pensieri, S., and Bozzano, R.: Upper layer current variability in the Central Ligurian Sea, Ocean Sci., 6, 825-836, doi:10.5194/os-6-8252010, 2010.

Pinot, J. and Jansá, J.: Time variability of acoustic backscatter from zooplankton in the Ibiza Channel (western Mediterranean), Deep Sea Res.-Pt. I, 48, 1651-1670, 2001.

Plueddemann, A. and Pinkel, R.: Characterization of the patterns of diel migration using a Doppler sonar, Deep Sea Res.-Pt. I, 36, 509-530, 1989.

Raybaud, V., Nival, P., Mousseau, L., Gubanova, A., Altukhov, D., Khvorov, S., Ibañez, F., and Andersen, V.: Short term changes in zooplankton community during the summer-autumn transition in the open NW Mediterranean Sea: species composition, abundance and diversity, Biogeosciences, 5, 1765-1782, doi:10.5194/bg-5-1765-2008, 2008.

RD Instruments: WinRiver User's Guide, available at: http://www.rdinstruments.com/smartlink/wr/support_docs/ WINRIV2UG.PDF (last access: 19 February 2014), 2007.

Ringelberg, J.: Diel Vertical Migration of Zooplankton in Lakes and Oceans: Causal Explanations and Adaptive Significances, Springer Netherlands, 2010. 
Rippeth, T. and Simpson, J.: Diurnal signals in vertical motions on the Hebridean Shelf, 1998.

Sammari, C., Millot, C., and Prieur, L.: Aspects of the seasonal and mesoscale variabilities of the Northern Current in the western Mediterranean Sea inferred from the PROLIG-2 and PROS-6 experiments, Deep Sea Res.-Pt. I, 42, 893-917, 1995.

Sardou, J. E. M. and Andersen, V.: Seasonal abundance and vertical distributions of macroplankton and micronekton in the Northwestern Mediterranean Sea, Oceanol. Ac., 19, 645-656, 1996.

Schott, F.: Measuring winds from underneath the ocean surface by upward looking acoustic Doppler current profilers, J. Geophys. Res.-Oceans, 94, 8313-8321, 1989.

Smith, R. O., Bryden, H. L., and Stansfield, K.: Observations of new western Mediterranean deep water formation using Argo floats 2004-2006, Ocean Sci., 4, 133-149, doi:10.5194/os-4-133-2008, 2008.

Sparnocchia, S., Schiano, M. E., Picco, P., Bozzano, R., and Cappelletti, A.: The anomalous warming of summer 2003 in the surface layer of the Central Ligurian Sea (Western Mediterranean), Ann. Geophys., 24, 443-452, doi:10.5194/angeo-24-443-2006, 2006.

Tarling, G., Matthews, J., David, P., Guerin, O., and Buchholz, F.: The swarm dynamics of northern krill (Meganyctiphanes norvegica) and pteropods (Cavolinia inflexa) during vertical migration in the Ligurian Sea observed by an acoustic Doppler current profiler, Deep Sea Res.-Pt. I, 48, 1671-1686, 2001.
Tarling, G. A., Buchholz, F., and Matthews, J.: The effect of lunar eclipse on the vertical migration behaviour of Meganyctiphanes norvegica (Crustacea: Euphausiacea) in the Ligurian Sea, J. Plankton Res., 21, 1475-1488, 1999.

Taupier-Letage, I. and Millot, C.: General hydrodynamical features in the Ligurian Sea inferred from the DYOME experiment, Oceanol. Ac., 9, 119-131, 1986.

Truscott, J. E. and Brindley, J.: Equilibria, Stability and Excitability in a General Class of Plankton Population Models, Philos. T. R. Soc. A, 347, 703-718, 1994.

van Haren, H.: Echo intensity data as a directional antenna for observing processes above sloping ocean bottoms, Ocean Dynam., 57, 135-149, 2007.

Vignudelli, S., Cipollini, P., Astraldi, M., Gasparini, G. P., and Manzella, G.: Integrated use of altimeter and in situ data for understanding the water exchanges between the Tyrrhenian and Ligurian Seas, J. Geophys. Res.-Oceans, 105, 19649-19663, 2000.

Visbeck, M. and Fischer, J.: Sea Surface Conditions Remotely Sensed by Upward-Looking ADCPs, J. Atmos. Ocean.-Tech., 12, 141-149, 1995.

Weikert, H. and Trinkaus, S.: Vertical mesozooplankton abundance and distribution in the deep Eastern Mediterranean Sea SE of Crete, J. Plankton Res., 12, 601-628, 1990. 